\title{
HIDROGENIONIC POTENTIAL (pH) OF THE ATTRACTANT, TRAP DENSITY AND CONTROL THRESHOLD FOR Ceratitis capitata (DIPTERA: TEPHRITIDAE) ON HAMLIN ORANGES IN SÃO PAULO CENTRAL REGION, BRAZIL ${ }^{1}$
}

\author{
PAULO EDUARDO BRANCO PAIVA² \& JOSÉ ROBERTO POSTALI PARRA²
}

ABSTRACT - This study evaluated the effect of initial $\mathrm{pH}$ values of 4.5, 6.5 and 8.5 of the attractant (protein bait) Milhocina ${ }^{\circledR}$ and borax (sodium borate) in the field, on the capture of fruit flies in McPhail traps, using 1, 2, 4 and 8 traps per hectare, in order to estimate control thresholds in a Hamlin orange grove in the central region of the state of São Paulo. The most abundant fruit fly species was Ceratitis capitata, comprising almost $99 \%$ of the fruit flies captured, of which $80 \%$ were females. The largest captures of $C$. capitata were found in traps baited with Milhocina ${ }^{\circledR}$ and borax at $\mathrm{pH}$ 8.5. Captures per trap for the four densities were similar, indicating that the population can be estimated with one trap per hectare in areas with high populations. It was found positive relationships between captures of $C$. capitata and the number of Hamlin oranges damaged, 2 and 3 weeks after capture. It was obtained equations that correlate captures and damage levels which can be used to estimate control thresholds. The average loss caused in Hamlin orange fruits by $C$. capitata was 2.5 tons per hectare or $7.5 \%$ of production.

Index terms: true fruit flies, protein bait, damage, IPM, Citros.

\section{POTENCIAL HIDROGENIÔNICO (pH) DO ATRATIVO, DENSIDADE DE ARMADILHAS E NÍVEL DE CONTROLE PARA Ceratitis capitata (DIPTERA: TEPHRITIDAE) EM LARANJA HAMLIN NA REGIÃO CENTRAL DE SÃO PAULO, BRASIL}

RESUMO - Esta pesquisa teve como objetivos: avaliar o efeito do $\mathrm{pH}$ inicial, $4.5 ; 6.5$ e 8.5, do atrativo proteico Milhocina ${ }^{\circledR}$ e bórax (tetraborato de sódio) na captura de moscas-das-frutas em armadilhas McPhail; estudar densidades de armadilhas, 1; 2; 4 e 8 por hectare, para estimar níveis de controle em laranja cv. Hamlin, na região central de São Paulo. A espécie predominante, com $99 \%$ das moscas-das-frutas capturadas, foi Ceratitis capitata, sendo $80 \%$ de fêmeas. As maiores capturas de C. capitata ocorreram nas armadilhas com Milhocina ${ }^{\circledR}$ e bórax em pH 8.5. As capturas, nas 4 densidades, foram semelhantes, indicando que a população pode ser estimada com uma armadilha por hectare em áreas de altas populações. Houve relações positivas entre capturas de C. capitata e o número de frutos danificados, 2 e 3 semanas após a captura. Assim, foram obtidas equações que relacionam a captura e o dano, possibilitando estimar níveis de controle desse inseto. As perdas médias causadas por C. capitata em laranja cv. Hamlin chegaram a 2,5 toneladas de frutos por hectare ou $7,5 \%$ da produção.

Termos para indexação: moscas-das-frutas, dano, atrativo proteico, MIP, Cítros.

'(Trabalho 139-12).Recebido em: 10-04-2012. Aceito para publicação em: 02-05-2013.

${ }^{2}$ Universidade de São Paulo, Escola Superior de Agricultura Luiz de Queiroz, Departamento de Entomologia e Acarologia, Avenida Pádua Dias, 11, CEP 13418-900 Piracicaba, SP, Brazil. E-mails: paulopaiva@usp.br, jrpparra@usp.br 


\section{INTRODUCTION}

The Mediterranean fruit fly, Ceratitis capitata (Wiedemann) (Diptera: Tephritidae), is one of the main fruit tree pests in the world. This species was recorded in Brazil at the end of the $19^{\text {th }}$ Century and is presently found in most Brazilian states (ZUCCHI, 2001). It is estimated that one box (40.8 $\mathrm{kg}$ ) of oranges per tree may be lost, in early maturing varieties; due to fruit flies (RAGA, 2005). Besides losses caused by the fall and subsequent rotting of fruits, there are sanitary restrictions to the export of fresh fruit to countries where these insects do not occur. Apart from C. capitata, citrus fruits in Brazil are also attacked by Anastrepha fraterculus (Wiedemann), Anastrepha obliqua (Macquart) (Diptera: Tephritidae) and flies of the Lonchaeidae family (MALAVASI; MORGANTE, 1980; SOUZA FILHO et al., 2000). In São Paulo, large populations of $C$. capitata develops in mature coffee fruits during the autumn-winter period, and these insects may move to citrus and other groves, where they can cause serious damage (SOUZA FILHO et al., 2000; ZUCCHI, 2001; MONTES et al., 2011).

Economically important fruit flies have been monitored using traps with food attractants (GARCIA; CORSEUIL. 1998; NASCIMENTO et al., 2000; SCOZ et al., 2006) or other components, such as trimedlure for $C$. capitata (GROUT et al., 2011). McPhail traps with hydrolyzed proteins, or similar products, have been the most used, despite being considered expensive, difficult to use and inefficient (ALUJA, 1994), because they are able to capture different tephritid species. Characteristics of the attractant suspension, such as attractant concentration and quality, $\mathrm{pH}$, addition of preservatives, production of ammonia and fermentation time, have influenced the capture efficiency of fruit flies (BATEMAN; MORTON, 1981; MAZOR et al., 1987; EPSKY et al., 1994; DUYCK et al., 2004; HEATH et al., 2009).

Pest population monitoring and utilization of control thresholds have become major components in integrated pest management programs (NORRIS et al., 2003). However, the best trap density for monitoring these insects in citrus is unknown and may depend on the fruit fly population. Although there are some indications on control thresholds for fruit flies (NASCIMENTO et al., 2000), little research has been done on the relationship between insect trap captures and the damage caused (AGUNLOYE, 1987; UCHÔA-FERNANDES et al., 2003; GROUT et al., 2011). The objectives of this research were to evaluate the effect of $\mathrm{pH}$ of the attractant suspension and also estimate the control threshold for $C$. capitata at four trap densities, based on captures and fruit damage in Hamlin variety (sweet orange).

\section{MATERIAL AND METHODS}

The experiment was conducted in a Hamlin grove (C. sinensis), an early maturing variety, in Itaju, central region of the state of São Paulo, Brazil, from June to August, 2002. The attractant used was a corn steep water, with $25 \%$ protein content, Milhocina ${ }^{\circledR}$ (Corn Products, Mogi-Guaçu, Brasil), which is an acid hydrolyzed corn protein product. Sodium tetraborate decahydrate (borax) was added to this at $5 \%$ (weight/volume) to preserve the attractant and the captured insects (LOPEZ; HERNANDEZ BECERRIL, 1967). The $\mathrm{pH}$ of the mixture was adjusted to 8.5 with a solution of sodium hydroxide. A portable $\mathrm{pH}$ meter (Checkmite $\mathrm{pH}-10$, Corning, NY) was used for verification. McPhail traps, MataSete ${ }^{\circledR}$ model (Isca Tec, Ijuí, Brazil), $13.5 \mathrm{~cm}$ tall, with a yellow $17 \mathrm{~cm}$ diameter base and a transparent upper portion, were used.

The attractant was diluted in water to $5 \%$ (volume/volume), and $250 \mathrm{ml}$ of the attractant suspension were placed in each trap. The traps were installed inside the orange trees in the shade at an approximate height of $1.5 \mathrm{~m}$ from the soil. Any branches beneath the trap that could stop or make the entrance of the insects more difficult were removed. The captured insects were separated by pouring the liquid trap contents onto a sieve, where they were retained. The sieve was then placed in a recipient with water and the insects were identified when they floated. The fruit flies were counted and C. capitata distinguished by sex, based on the male antennae and female ovipositor (ZUCCHI, 2001). Anastrepha species were identified by M. F. Souza Filho and Lonchaeidae by P. Strikis.

Effect of pH of the attractant on $C$. capitata capture. The experiment was conducted in a sweet orange grove (C. sinensis), with an early maturing Hamlin variety, in Itaju, central region of the state of São Paulo, Brazil, in June, 2002. The grove occupied an area of 10 hectares, with 5-year old trees, without fruits, and was harvested a week before the experiment began. The trees, spaced 7.5 by $3 \mathrm{~m}$, were 2 to $2.5 \mathrm{~m}$ high. The experimental design was completely random with four attractants (treatments), (1) Milhocina ${ }^{\circledR}$ in $\mathrm{pH} 4.5$, (2) Milhocina ${ }^{\circledR}+$ borax in $\mathrm{pH} 4.5$, (3) Milhocina ${ }^{\circledR}+$ borax in $\mathrm{pH} 6.5$ and (4) Milhocina ${ }^{\circledR}+$ borax in $\mathrm{pH} 8.5$, with six repetitions. The attractant was diluted to $5 \%$ and placed in the traps. These traps were randomly 
distributed, maintaining $30 \mathrm{~m}$ distance between them. Evaluations were made 2, 4, 6 and 8 days after installation, by counting captured fruit flies and measuring the $\mathrm{pH}$. The traps were again randomized after each evaluation.

Effect of trap density on $C$. capitata capture and the relationship with damaged Hamlin orange fruits. The experiment was conducted in a Hamlin grove (C. sinensis), in Itaju, state of São Paulo, Brazil, between June and August, 2002, when there were large $C$. capitata populations, probably originating from coffee (Coffea arabica L.). The experimental area consisted of two neighboring 14 hectare plots, with 5-year old trees, 2 to $2.5 \mathrm{~m}$ high, within a continuous 700 ha area of citrus. Fruits were yellowish, approximately 9 months old (originating from flowering in October 2001), and were mature at the beginning of the experiment and ready for harvesting. The inter-tree spacing was 7.5 by $3 \mathrm{~m}$, with a density of 444 trees per hectare.

The treatments were one, two, four and eight traps per hectare, with 5 repetitions. The experimental design was completely random, with plots of 100 by 100 meters. The traps were distributed equidistantly from each other inside the plot, with at least $25 \mathrm{~m}$ between them, one trap per tree. The traps were installed in the morning and the fruit fly evaluation was realized in the following morning, 24 hours later, since a preliminary evaluation of 7 days of captures had observed insect decomposition due to the excess number of insects collected. The trap contents were sieved and the insects identified, with fruit flies being separated by sex. The traps were kept on the trees without attractant suspension until the next evaluation, one week later.

Damage was evaluated by tagging nine trees at random within each plot and counting the number of damaged fruits by fruit fly, on the tree and on the ground. At the beginning of the experiment, all damaged fruits were removed from the tagged trees. At each evaluation, the damaged fruits were removed from the tagging trees, so they would not be recounted at the next evaluation.

Linear regressions, considering fruit damage as dependent variable, and the capture, one, two and three weeks later, was calculated at the four trap densities. The treatments were compared by analyses of variances (F test). All statistical analyses were conducted on SAS (SAS Institute, 2000).

\section{RESULTS AND DISCUSSION}

Effect of $\mathrm{pH}$ of attractant on C. capitata capture. Only $C$. capitata was captured in this experiment. The initial $\mathrm{pH}$ of the attractant suspension of Milhocina ${ }^{\circledR}+$ borax influenced the capture of $C$. capitata flies in a Hamlin orange grove with no fruits $(\mathrm{F}=77.26$, d.f. $=2 ; 70, \mathrm{P}<0.01)($ Figure 1$)$.

The mean number of $C$. capitata captured in two days in the most efficient suspension ( $\mathrm{pH} 8.5$ ) was 42.6 flies per trap, six times higher than that observed for the Milhocina ${ }^{\circledR}+$ borax suspension of $\mathrm{pH} 4.5$, that is, 7.1 flies per trap. Similar results were observed by Bateman and Morton (1981) for Bractrocera tryoni (Froggatt) and the attractant NBC, where the mean capture was nine times higher for $\mathrm{pH} 8.5$ than for the standard attractant with a $\mathrm{pH}$ of 4.8. With the NuLure attractant, the highest captures of female C. capitata also occurred at a $\mathrm{pH}$ of 8.5 (EPSKY et al., 1994).

There was no difference between captures in traps with an attraction suspension $\mathrm{pH}$ of 4.5 , with and without borax $(\mathrm{F}=1.78$, d.f. $=1 ; 46, \mathrm{P}$ $=0.19)$. Thus, the addition of sodium tetraborate decahydrate (borax) to the $5 \%$ attractant concentrate did not influence the capture of $C$. capitata with an acid $\mathrm{pH}$ of 4.5 . The addition of 1,2 and $3 \%$ borax to the protein attractant PIB-7 ( $\mathrm{pH}$ of 8.5 to 9) reduced the capture of Anastrepha ludens (Loew) (LOPEZ: HERNANDEZ; BECERRIL, 1967). Substances which inhibit microorganism development can reduce ammonia production (BATEMAN; MORTON, 1981), and, consequently, reduce the capture of tephritids.

The addition of $1 \%$ borax to the protein attractant PIB-7 allowed the stabilization of the suspension $\mathrm{pH}$ to 8.7 for up to 7 days, suggesting that attractant decomposition was inhibited (LOPEZ; HERNANDEZ BECERRIL, 1967). Epsky et al. (1994) verified that the number of female Anastrepha suspensa (Loew) fell with the addition of 3,5 and $10 \%$ borax, and there was a stabilization of the solution $\mathrm{pH}$ at these concentrations. The present study used $5 \%$ borax in the attractant, which diluted to $5 \%$ in water resulted in a final borax concentration of $0.25 \%$ and this concentration was unable to avoid $\mathrm{pH}$ variations in the attractant suspensions and affect C. capitata capture, at $\mathrm{pH}$ of 4.5 .

Effect of trap density on $C$. capitata capture in Hamlin variety oranges. A total of 51,532 fruit flies were collected, of which 50,956 were $C$. capitata, 304 tephritids of the genera Anastrepha (A. obliqua, Anastrepha serpentina 
(Wiedemann) and Anastrepha sororcula Zucchi) and 272 were loncheids of the genera Neosilba [(Neosilba zadolicha McAlpine and Steyskal, Neosilba pendula (Bezzi) and Neosilba sp.)]. The mean percentage of females in the captures was $92 \%$ for Neosilba, $80 \%$ for C. capitata and 58\% for Anastrepha.

In general, C. capitata captures per trap were unaffected by trap density (Figure 2). Thus, independent of the trap density of one, two, four or eight traps per hectare, the number of $C$. capitata captured per trap did not differ statistically between the different trap densities for the six evaluations.

Although there were no differences between C. capitata captures for each evaluation, when the captures for all the evaluations were considered, there was a significant difference for the total number of flies captured $(\mathrm{F}=3.71$, d.f. $=3 ; 446, \mathrm{P}=0.012)$ and females $(\mathrm{F}=4.22$, d.f. $=3 ; 446, \mathrm{P}<0.01)$, but not for males $(\mathrm{F}=1.64$, d.f. $=3 ; 446, \mathrm{P}=0.18)$. Considering the six evaluations, the highest individual trap captures were observed for the smallest trap density studied, one trap per hectare.

Relationship between $C$. capitata capture and damage in Hamlin oranges. Since the predominant species was $C$. capitata, corresponding to almost $99 \%$ of fruit flies captured, linear regressions were estimated between this insect capture and damage to ripe oranges. There was a positive correlation between $C$. capitata capture and the damage caused by these insects in the second and third week after capture (Table 1, Figure 3). There was no correlation between $C$. capitata captures and the damage in the same week to capture and in the first week.

Contrary to the result obtained in the present study, Agunloye (1987) concluded there was no relationship between the number of $C$. capitata captured in traps (with honey and sugar) and the number of damaged oranges, in plots of 4 trees. Uchôa-Fernandes et al. (2003) also observed no correlation $(\mathrm{p}<0.01)$ between Neosilba captured in traps containing protein attractant in orange groves and the number of larvae and adults of these flies in attacked fruits. Agunloye (1987) used small plots and Uchôa-Fernandes et al. (2003) found a positive correlation of Neosilba sp. captured in traps and adults emerged in oranges $(\mathrm{p}=0.036)$.

Since it is the female fruit flies which damage the fruits by ovipositing, the correlation between female trap captures and damaged fruits seemed to be more probable than the capture of both males and females. However, although females were the majority in the captures $(80 \%)$, there was also a correlation with the capture of males and females together. Therefore, separating insects by sex when monitoring $C$. capitata is unnecessary.

As the efficacy of fruit fly monitoring with food attractants (NASCIMENTO; CARVALHO, 2000) and capture have been considered low (ALUJA, 1994), trap captures would not represent the population of the monitoring area. Since there was a correlation between $C$. capitata capture and damage caused to Hamlin fruits, there should also have a correlation between the resident population of the area and the damage. Therefore, it may be inferred from the results obtained that a relationship may exist between the resident population of $C$. capitata and trap captures.

Using the linear equation obtained (Figure 3), for a capture of 50 C. capitata per trap per day, Hamlin oranges damaged is estimated in $230 \mathrm{~kg} /$ hectare. However, before a general recommendation can be made, control threshold should be tested and validated in different groves. At high population levels, the first capture may already be higher than this control threshold. However, if the females are in the pre-oviposition stage there will be enough time to begin control and avoid damage.

Damage caused by $C$. capitata in Hamlin oranges. With an accumulated mean damage of 306.7 fruits on 9 trees over 6 weeks (density of 444 orange trees per hectare and fruit weight of $165 \mathrm{~g}$ ), a mean loss was estimated in $2,495 \mathrm{Kg}$ of fruits per hectare. Losses within plots varied between 1,354 and $4,458 \mathrm{Kg}$ of fruits per hectare (Figure 4).

Mean losses of 2.5 tons of fruits per hectare were estimated or $7.5 \%$ of the total production. This value is lower than that estimated by Raga (2005), and occurred under these experimental conditions due to three factors: a high C. capitata population, an advanced stage of fruit maturation, about two months after the harvest time, and no chemical control of the insect. However, in large areas of oranges, harvesting delays are common and the level of losses observed in the present study may occur. 
TABLE 1 - Values $\mathrm{F}$ and $\mathrm{P}$ for linear regressions between mean number of Ceratitis capitata captured per McPhail trap and the mean number of damaged fruits in 9 trees at the same week to capture (week 0), one (week 1), two and three weeks (week 3) after capture.

\begin{tabular}{cccccc}
\hline capture x damage & $\mathrm{F}$ & $\mathrm{P}$ & d.f. $^{1}$ & linear equation & $\mathrm{r}^{2}$ coefficient \\
\hline damage week 0 & 1.85 & 0.18 & $1 ; 118$ & - & - \\
damage week 1 & 0.03 & 0.84 & $1 ; 98$ & - & - \\
damage week 2 & 7.96 & $<0.01$ & $1 ; 78$ & $\mathrm{Y}=0.12 \mathrm{X}+38.14$ & 0.10 \\
damage week 3 & 49.91 & $<0.01$ & $1 ; 58$ & $\mathrm{Y}=0.26 \mathrm{X}+25.98$ & 0.35 \\
\hline
\end{tabular}

${ }^{1}$ : degrees of freedon for regression and residue.

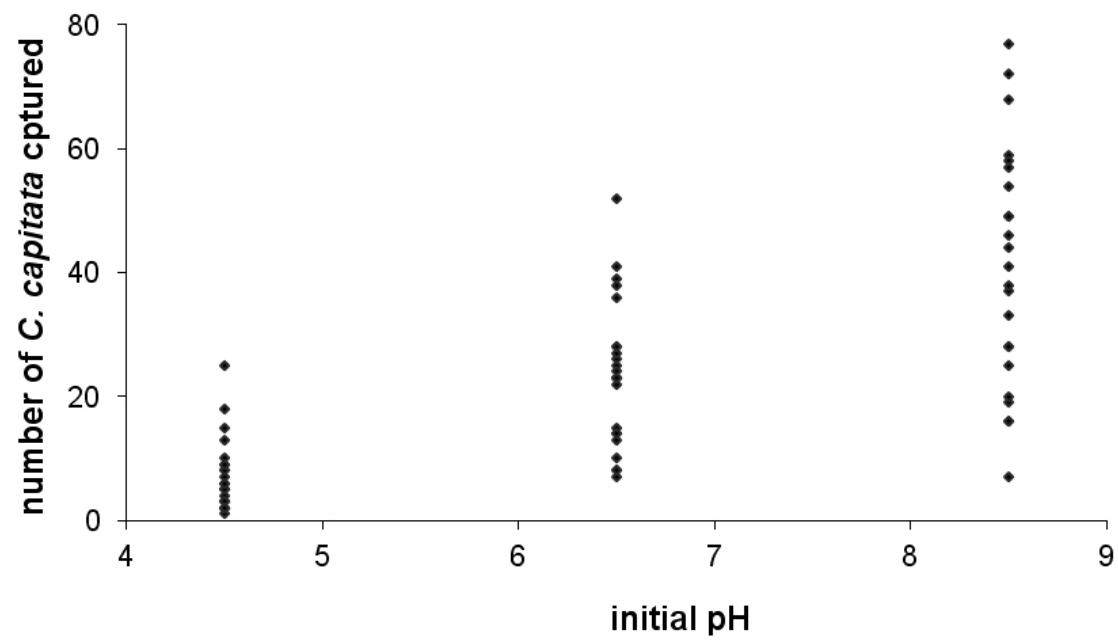

FIGURE 1- Effect of initial pH of attractant suspension of Milhocina ${ }^{\circledR}$ and borax on Ceratitis capitata capture, in a Hamlin orange grove without fruits. Itaju / SP.

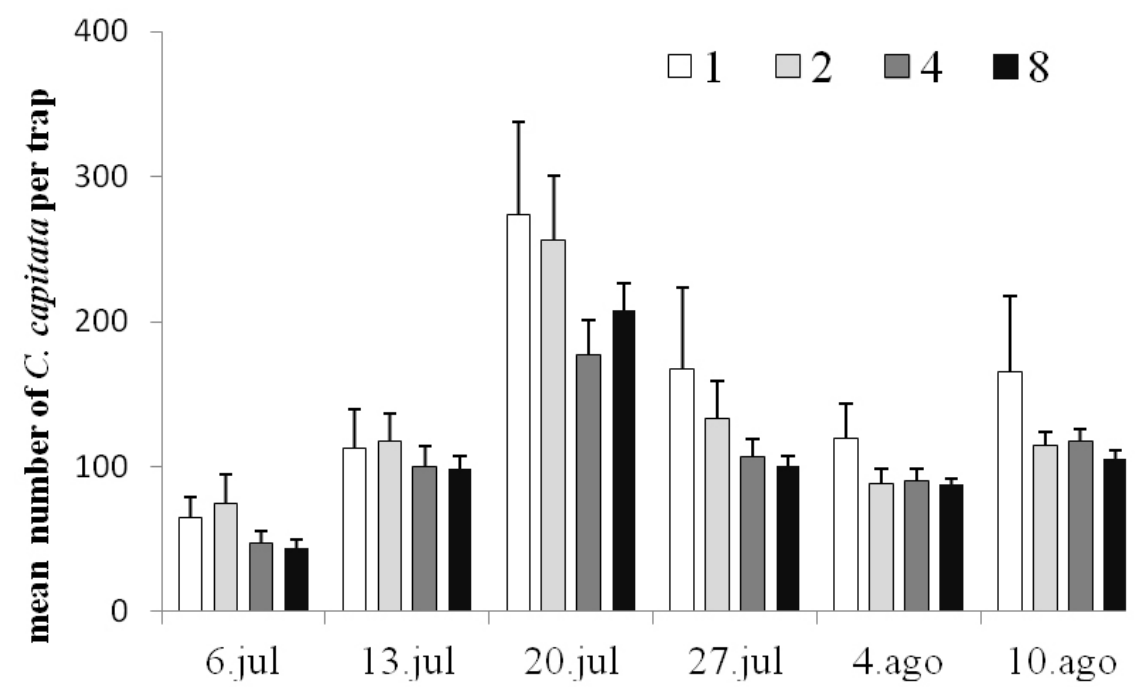

FIGURE 2- Mean number of Ceratitis capitata captured (standard error of mean) in one day, in a Hamlin orange grove with fruits, at 1, 2, 4 and 8 traps per hectare. Itaju / SP. 


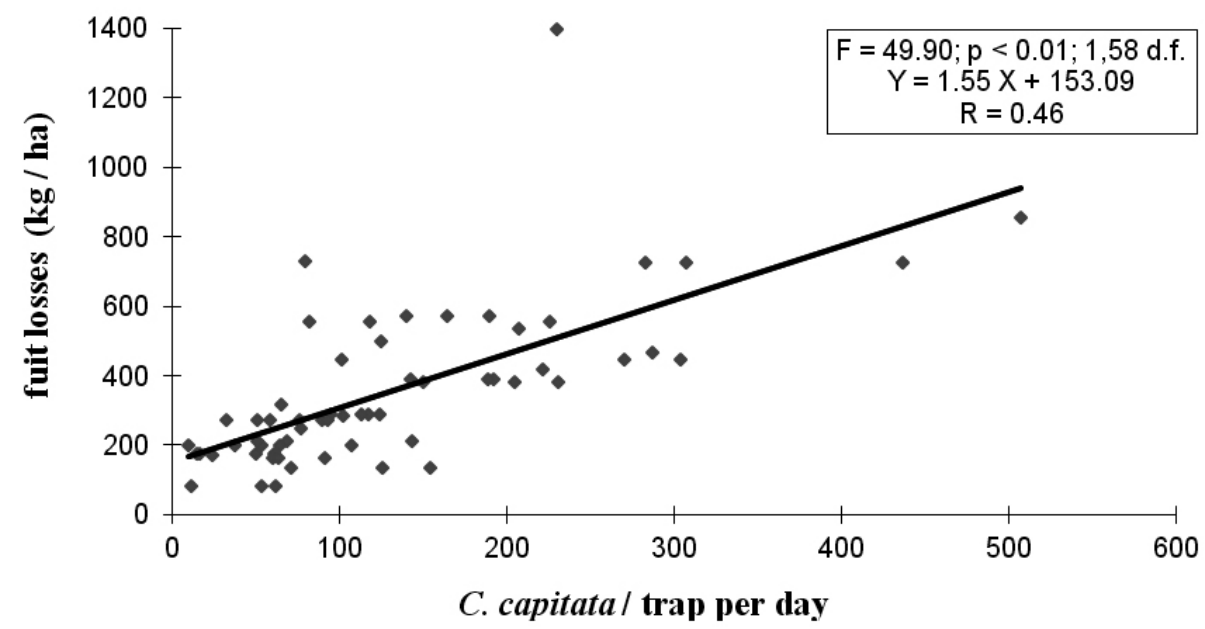

FIGURE 3 - Positive correlation between mean numbers of Ceratitis capitata captured per day and the orange fruit losses 3 weeks later. Itaju / SP, 2002.

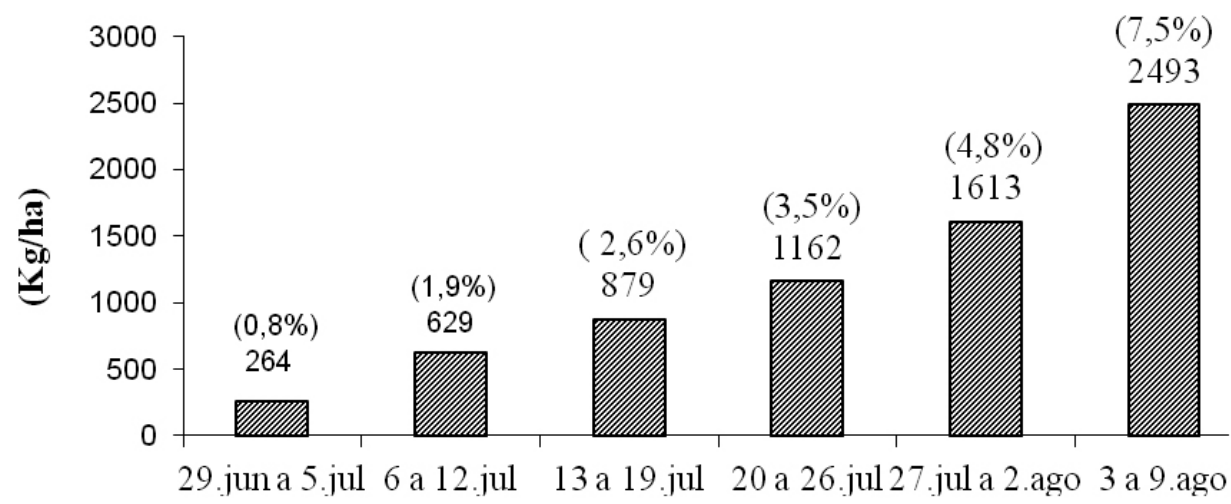

FIGURE 4- Accumulated mean damage caused by Ceratitis capitata to mature fruits of Hamlin oranges (percentage of losses in relation to total harvested). Itaju / SP.

\section{CONCLUSIONS}

1- The highest captures of Ceratitis capitata in McPhail traps occur with Milhocina ${ }^{\circledR}$ and borax adjusted to a $\mathrm{pH}$ of 8.5 .

2- The mean number of C. capitata individuals captured is similar for the different trap densities, and this insect can be estimated at a trap density of 1 per hectare in areas with high insect populations.

3- There are positive correlations between the number of captured C. capitata and the number of damaged Hamlin oranges, two and three weeks after, allowing the estimation of control thresholds.

\section{ACKNOWLEGEMENTS}

We are thankful to S. Silveira Neto for initial discussions, to M. F. Souza Filho and P. Strikis for insect identifications and also to the reviewer for suggestions.

\section{REFERENCES}

AGUNLOYE, O.J. Trapping and chemical control of Ceratitis capitata (Wied.) (Diptera: Tephritidae) on sweet orange (Citrus sinensis) in Nigeria. Journal of Horticultural Science, Ashford, v.62, n.2, p. 269-271, 1987.

ALUJA, M. Bionomics and management of Anastrepha. Annual Review of Entomology, Palo Alto, v. 39, p. 155-178, 1994. 
BATEMAN, M.A.; MORTON, T.C. The importance of ammonia in proteinaceous attractants for fruit flies (Family: Tephritidae). Australian Journal of Agricultural Research, Victoria, v. 32, p. 883-903, 1981.

DUYCK, P. F.; ROUSSE, P.; RYCKEWAERT, P.; FABRE, F.; QUILICI, S. Influence of adding borax and modifying $\mathrm{pH}$ effectiveness of food attractants for melon fly (Diptera: Tephritidae). Journal of Economic Entomology, Lanham, v. 97, n. 3, p.11371141, 2004.

EPSKY, N. D.; HEATH, R. R.; HOLLER, T. C.; HARRIS, D. L.; MULLINS, T. Corn steepwater as protein bait for Anastrepha suspensa (Diptera: Tephritidae). Journal of Economic Entomology, Laham, v. 23, n.4, p.827-831, 1994.

GARCIA, F. R. M.; CORSEUIL, E. Flutuação populacional de Anastrepha fraterculus (Wiedemann) e Ceraitis capitata (Wiedemann) (Diptera, Tephritidae) em pomares de pessegueiro em Porto Alegre, Rio Grande do Sul. Revista Brasileira de Zoologia, Curitiba, v.15, n.1, p.153-158, 1998.

GROUT, T. G.; DANEEL, J. H.; WARE, A. B.; BECK, R. R. A comparison of monitoring systems used for Ceratitis species (Diptera: Tephritidae) in South Africa. Crop Protection, Madison, v.30, n.6, p. $617-622,2011$

HEATH, R. R.; VAZQUEZ, A.; SCHNELL, E. Q.; VILLAREAL, J.; KENDRA, P. E.; EPSKY, N. D. Dynamics of $\mathrm{pH}$ modification of an acidic protein bait used for tropical fruit flies (Diptera: Tephritidae). Journal of Economic Entomology, Laham,v.102, n.6, p. 2371-2376, 2009.

LOPEZ, F. D.; HERNANDEZ BECERRIL, O. Sodium borate inhibits decomposition of two protein hydrolysates attractive to the Mexican fruit fly. Journal of Economic Entomology, Laham,v. 60, n.1, p. 137-140, 1967.

MALAVASI, A.; MORGANTE, J. S. Biologia de "moscas-das-frutas" (Diptera: Tephritidae). II: Índices de infestação em diferentes hospedeiros e localidades. Revista Brasileira de Biologia, Rio de Janeiro, v. 40, n. 1, p. 17-24, 1980.

MAZOR, M., GOTHILF, S.; GALUN, R. The role of ammonia in the attraction of females of the Mediterranean fruit fly to protein hydrolysate baits. Entomologia Experimentalis et Applicata, Drodrecht, v. 43 , n. 1 , p. 25-29, 1987
MONTES, S. M. N. M.; RAGA, A.; BOLIANI, A. C.; SANTOS. P. C. Dinâmica populacional e incidência de moscas-das-frutas e parasitoides em cultivares de pessegueiros (Prunus persica L. Batsch) no município de Presidente Prudente-SP. Revista Brasileira de Fruticultura, Jaboticabal, v. 33, n. 2, p. 402-411, 2011 .

NASCIMENTO, A.S.; CARVALHO, R.S. Manejo integrado de moscas-das-frutas. In: MALAVASI, A.; ZUCCHI, R.A. (Ed.). Moscas-das-frutas de importância no Brasil: conhecimento básico e aplicado. Ribeirão Preto: Holos, 2000. p. 169-173.

NASCIMENTO, A.S.; CARVALHO, R.S.; MALAVASI, A. Monitoramento populacional. In: MALAVASI, A.; ZUCCHI, R.A. (Ed.). Moscas-dasfrutas de importância no Brasil: conhecimento básico e aplicado. Ribeirão Preto, Brasil: Holos, 2000. p. 109-112.

NORRIS, R. F.; CASWELL-CHEN, E. P.; KOGAN, $\mathrm{M}$. Concepts in integrated pest management. New Jersey: Pearson Education, 2003. 586 p.

RAGA, A. Incidência, monitoramento e controle de moscas-das-frutas na citricultura paulista. Laranja, Cordeirópolis, v.26, n.2, p.307-322, 2005.

SCOZ, P. L.; BOTTON, M.; GARCIA, M. S.; PASTOR, P . L. Avaliação de atrativos alimentares e armadilhas para o monitoramento de Anastrepha fraterculus (Wiedemann, 1830) (Diptera: Tephritidae) na cultura do pessegueiro (Prunus persica (L.) Batsh). Idesia, Arica, v.24, n.2, p.7-13, 2006.

SAS Institute. SAS users guide: statistics version 8.02 for Windows. Cary, 2000.

SOUZA FILHO, M.F.; RAGA, A.; ZUCCHI, R.A. São Paulo. In: MALAVASI, A.; ZUCCHI, R.A. (Ed.). Moscas-das-frutas de importância no Brasil: conhecimento básico e aplicado. Ribeirão Preto: Holos, 2000. p.277-283.

UCHÔA-FERNANDES, M.A.; OLIVEIRA, I.; MOLINA, I.R.M.S.; ZUCCHI, R.A. Populational fluctuation of frugivorous flies (Diptera: Tephritoidea) in two orange groves in the state of Mato Grosso do Sul, Brazil. Neotropical Entomology, Londrina, v. 32, n.1, p. 19-25, 2003.

ZUCCHI, R. A. Mosca-do-mediterrâneo, Ceratitis capitata (Diptera: Tephritidae). In: VILELA, E. F.; ZUCCHI, R. A.; CANTOR, F. (Ed.). Histórico e impacto das pragas introduzidas no Brasil. Ribeirão Preto: Holos, 2001. p. 15-22. 